\title{
Accumulation of silver and lead in estuarine microzooplankton
}

\author{
Nicholas S. Fisher ${ }^{1}$, Vincent T. Breslin ${ }^{1}$, Michael Levandowsky ${ }^{2, *}$ \\ ${ }^{1}$ Marine Sciences Research Center, State University of New York, Stony Brook, New York 11794-5000, USA \\ ${ }^{2}$ Haskins Laboratories, Pace University, New York, New York 10038-1502, USA
}

\begin{abstract}
Accumulation of $\mathrm{Pb}$ and $\mathrm{Ag}$ by the estuarine ciliate Fabrea salina was measured using the $\gamma$-emitting radioisotopes ${ }^{210} \mathrm{~Pb}$ and ${ }^{110 \mathrm{~m}} \mathrm{Ag}$. Volume/volume concentration factors for ${ }^{110 \mathrm{~m}} \mathrm{Ag}$ in the ciliate ranged from 7 to $40 \times 10^{3}$; concentration factors of ${ }^{110 \mathrm{~m}} \mathrm{Ag}$ in $F$. salina from the dissolved phase and from radiolabeled algal food were comparable. The concentration factor of ${ }^{210} \mathrm{~Pb}$ obtained from the dissolved phase was $2 \times 10^{2}$; there was no detectable assimilation of ${ }^{210} \mathrm{~Pb}$ from algal food. Because estuarine microzooplankton can concentrate some particle-reactive trace metals out of ambient water, they can serve as a source of these metals for animals which consume them. For comparison, uptake of these radioisotopes from the water by various size fractions of natural particles in Hudson River (New York, USA) water was determined. Half of the added ${ }^{110 \mathrm{~m}} \mathrm{Ag}$ and $<36 \%$ of the added ${ }^{210} \mathrm{~Pb}$ remained in the dissolved (i.e. $<50 \mathrm{kDa}$ ) phase, with the remainder partitioned among different fractions of the suspended particulate matter, including the fraction containing the microzooplankton. Naturally occurring $\mathrm{Ag}$ and $\mathrm{Pb}$ concentrations in Hudson River suspended particulate matter showed a fractionation pattern similar to that of the radioisotopes. Comparison of $\mathrm{Ag} / \mathrm{Al}$ and $\mathrm{Pb} / \mathrm{Al}$ ratios in particles from the lower Hudson indicated an enrichment factor of 1 to 2 orders of magnitude for these metals over particles from other estuaries.
\end{abstract}

KEY WORDS: Ciliates · Protozoa · Microzooplankton · Lead · Silver · Trace metals

\section{INTRODUCTION}

The importance of the microzooplankton as grazers of small phyto- and bacterioplankton in coastal and open-ocean ecosystems has been recognized (Heinbokel \& Beers 1979, Capriulo \& Carpenter 1983, Sherr \& Sherr 1987, Caron \& Goldman 1990), and these organisms are in turn important food sources for diverse predators, including juvenile fish and larger zooplankton (Berk et al. 1977, Robertson 1983, Turner \& Anderson 1983, Kentouri \& Divanach 1986, Stoecker et al, 1987, Stoecker \& Capuzzo 1990, Small \& Ellis 1992). Despite the significant ecological role played by the microzooplankton in the trophic transfer of fixed carbon, there have been very few studies to address the interactions of these organisms with toxic chemi-

\footnotetext{
-Also associated with The River Project, Manhattan, New York, USA
}

cals, including metals (Berk et al. 1986). Since phytoplankton, including coccoid cyanobacterial picoplankton, can appreciably concentrate many metals out of seawater (Fisher 1985, 1986), they can serve to introduce these metals into the marine food web via grazing by microzooplankton.

There is an absence of studies which have specifically examined the trophic transfer of metals from food to microzooplankton. Hutchins \& Bruland (1994) reported that protozoa appeared to enhance the remineralization of iron from picoplankton in seawater, although they point out that further study is warranted owing to difficulties in quantitatively recovering intact protozoan cells. Similar results have been obtained in lake water, in which Ochromonas danica enhanced the remineralization rates of $\mathrm{Cd}$ and $\mathrm{Zn}$ from picoplanktonic cyanobacteria (M. Twiss, Univ. Quebec, pers. comm.).

This study presents the results of laboratory experiments which measured the bioaccumulation of 2 
metals, $\mathrm{Ag}$ and $\mathrm{Pb}$, in a representative cosmopolitan estuarine ciliate from both dissolved and ingested source terms. These metals are of considerable concern in coastal waters near large population centers and industrial activity, where their concentrations in sediments and organisms are elevated much above those in more remote regions (NOAA 1989, 1991). To address this issue, we measured the bioavailability of $\mathrm{Ag}$ and $\mathrm{Pb}$ to estuarine microzooplankton in a local estuary (the Hudson estuary, New York, USA) in which the microzooplankton are a prominent feature of the planktonic assemblage (Gold \& Morales 1975, Lom \& Cosper 1994, M. Levandowsky unpubl.). Levels of Ag and $\mathrm{Pb}$ are elevated in suspended particulate matter in the Hudson Raritan estuary (Brosnan \& O'Shea 1993). Both metals are concentrated about $10^{5}$ times out of seawater by phytoplankton (Fisher 1986) and both can be toxic to these organisms (Rivkin 1979, Fisher et al. 1984). Also, metal uptake in cultured ciliates was compared with metal uptake by natural particle assemblages in surface waters of the lower Hudson estuary to better understand the cycling of these metals in the Hudson.

\section{MATERIALS AND METHODS}

The estuarine heterotrich ciliate Fabrea salina was used as a model protozoan for determining rates and routes of metal uptake in single-celled animals. This cosmopolitan, aloricate organism has the advantage that it is readily cultured and maintained in the laboratory and it can be non-destructively transferred (or harvested) by gentle straining through a $37 \mu \mathrm{m}$ Nitex mesh immersed in water. The strain used in our experiments was originally isolated by Dr D. Kahan, Hebrew University, Israel. Cells were maintained in clean, glass-fiber (GFF)-filtered surface water obtained $8 \mathrm{~km}$ off Southampton, New York, with the salinity adjusted to $24 \%$ with deionized water. The volume of each $F$. salina cell, measured with a Coulter Counter, is approximately $67000 \mu^{3}$. Owing to difficulties in direct determination of the dry weight of individual $F$. salina cells in saline water (due to salt interference and the fragility of the cells to ammonium formate rinses), the dry weight was estimated by applying the mean dry weight:volume ratio of other non-mineralized cells, including the freshwater ciliate Tetrahymena thermophila $\left(0.11 \mathrm{pg}^{-3} \mathrm{~m}^{-3}\right.$; unpubl. data) and the wall-less marine chlorophyte Dunaliella tertiolecta $\left(0.16 \mathrm{pg} \mu \mathrm{m}^{-3}\right.$. Fisher et al. 1984). Based on these ratios from other comparable protists and the measured cell volume, we assume a dry weight for $F$, salina of $9 \mathrm{ng} \mathrm{cell}^{-1}$.

This study examined metal uptake by tracing the biological interactions of the metals with $\gamma$-emitting radiotracers. Application of radiotracer methodology, using experimental protocols developed for other marine microorganisms (Fisher et al. 1983a), enables rapid and precise measurements of metal accumulation into organisms at environmentally realistic metal concentrations. To measure metal uptake by Fabrea salina cells from solution over a $24 \mathrm{~h}$ period, cells were added to sterile-filtered (through sterile $0.2 \mu \mathrm{m}$ Nuclepore filters) water (SFW) and their food vacuoles were allowed to clear over a $3 \mathrm{~h}$ period. They were then harvested and transferred to fresh SFW to which radioisotopes of $\mathrm{Ag}$ and $\mathrm{Pb}$ were added. Experiments used 180 ciliates in $25 \mathrm{ml}$ of SFW contained in $60 \mathrm{ml}$ capacity snap-cap polypropylene vials, each containing $50 \mathrm{kBq}^{-1}$ of ${ }^{110 \mathrm{~m}} \mathrm{Ag}$ (33 $\mathrm{nM} \mathrm{Ag}$ addition) or $37 \mathrm{kBq} \mathrm{l^{-1 }}$ of ${ }^{210} \mathrm{~Pb}$ (62 $\mathrm{fM} \mathrm{Pb}$ addition). The ${ }^{110 \mathrm{~m}} \mathrm{Ag}$ $\left(t_{1 / 2}=250 \mathrm{~d}\right)$ was dissolved in $0.1 \mathrm{~N}$ Ultrex $\mathrm{HNO}_{3 \mathrm{i}}$ the ${ }^{210} \mathrm{~Pb}\left(t_{1 / 2}=22.3 \mathrm{yr}\right)$ was dissolved in $3 \mathrm{~N}$ Ultrex $\mathrm{HNO}_{3}$. Water samples received $\mu \mathrm{l}$ quantities of Suprapur $\mathrm{NaOH}$ immediately prior to radiotracer addition so that the final $\mathrm{pH}$ of the water was unaffected by the acidic radioactive additions. Sorption of the ${ }^{110 \mathrm{~m}} \mathrm{Ag}$ to the apparatus walls, determined with acid washing procedures (Fisher et al. 1984) for cultures containing total Ag concentrations of 10 to $1000 \mathrm{nM}$, ranged from 0 to $1.65 \%$ of the total $\mathrm{Ag}$ present.

To measure uptake by Fabrea salina over $24 \mathrm{~h}$ from food, log-phase cultures of the naked prymnesiophyte Isochrysis galbana were uniformly radiolabeled with ${ }^{110 \mathrm{~m}} \mathrm{Ag}$ or ${ }^{210} \mathrm{~Pb}$ and resuspended out of their radioactive media via centrifugation (Fisher \& Wente 1993); these cells were used to create a feeding suspension of $2 \times 10^{4}$ radiolabeled cells $\mathrm{ml}^{-1}$. I. galbana is an excellent food source for F. salina (Repak 1983). Each Ag-labeled $I$. galbana cell contained 83 to $120 \mu \mathrm{Bq}$ of ${ }^{110 \mathrm{~m}} \mathrm{Ag}$ or 2.3 to $3.3 \times 10^{-17} \mathrm{~mol} \mathrm{Ag}$ (total 0.45 to $0.65 \mathrm{nM}$ Ag addition), depending on the experiment. Each ${ }^{210} \mathrm{~Pb}$-labeled cell contained $180 \mu \mathrm{Bq}$ of ${ }^{210} \mathrm{~Pb}$. Desorption of radioisotope from the radiolabeled $I$. galbana cells into the dissolved phase in the labeled feeding suspensions was determined over time (Fisher \& Wente 1993). The effects of gut clearance on Ag concentration factors in $F$. salina fed radioactive food were determined by allowing aliquots of radiolabeled ciliates to feed upon a dense culture $\left(1 \times 10^{5} \mathrm{cells} \mathrm{m}^{-1}\right)$ of unlabeled $I$. galbana cells for $1 \mathrm{~h}$ prior to radioactive counting of the ciliates.

To collect radiolabeled Fabrea salina cells, we screened the algae plus ciliate mixture using a $37 \mu \mathrm{m}$ Nitex mesh (to separate the ciliates from the radiolabeled Isochrysis galbana cells which passed through this mesh) and then washed off the mesh onto a $10 \mu \mathrm{m}$ Nuclepore filter using a wash bottle with SFW. Finally, the filter was rinsed twice with $5 \mathrm{ml}$ of unlabeled SFW and its radioactivity counted. Microscopic checks con- 
firmed that no $I$. galbana cells were included in the samples containing $F$. salina cells.

To compare the fractionation of radioactive and stable metal isotopes, and to check whether $\mathrm{Ag}$ and $\mathrm{Pb}$ fractionated on particles of comparable size to microzooplankton in the Hudson, surface water samples were taken at 3 different times of the year from the end of Pier 26 at The River Project in Manhattan in the lower Hudson (mean depth $7 \mathrm{~m}$ ). Water samples were obtained with acid-washed 2.51 polycarbonate containers. The salinities of surface waters and at $7 \mathrm{~m}$ depth at this site, sampled weekly over a $2 \mathrm{yr}$ period, indicate a frequently stratified water column, although temperature differences between surface and bottom water did not differ by more than $2^{\circ} \mathrm{C}$ (Fig. 1). The water was nearly always turbid and Secchi disk values
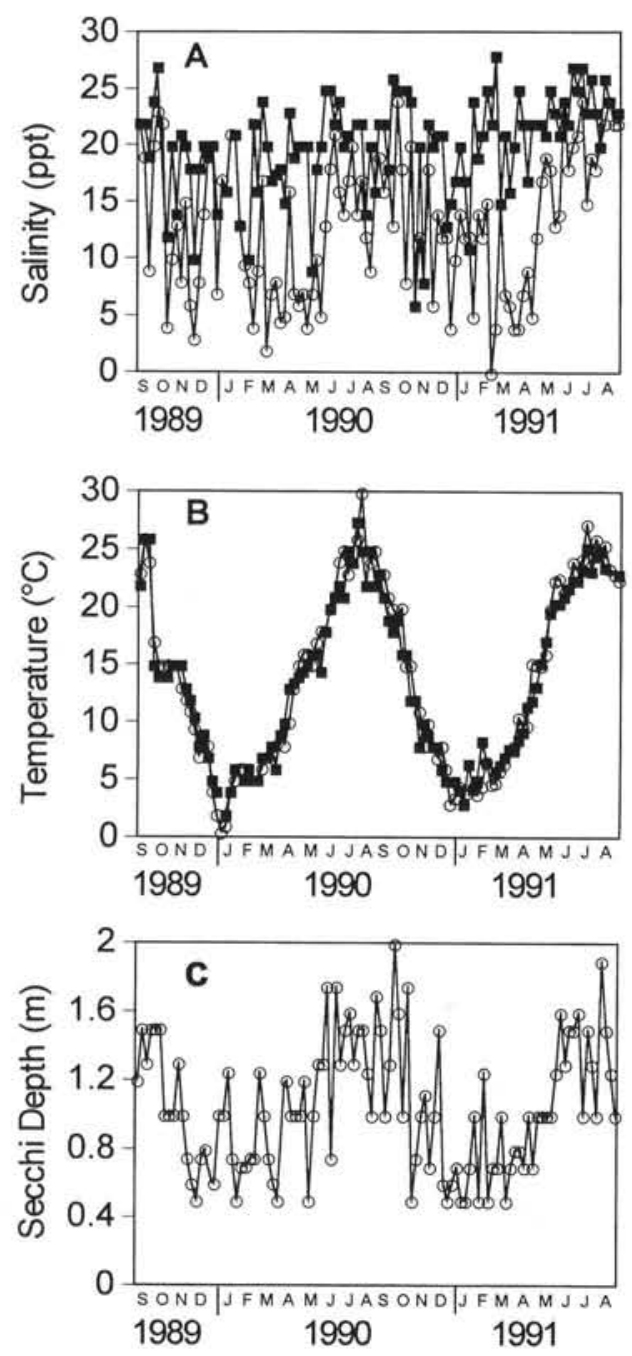

Fig. 1. (A). Surface (0) and bottom ( $7 \mathrm{~m}$; घ) salinities, (B) surface (O) and bottom (w) temperatures, and (C) Secchi disk depths of water at the end of Pier 26, Manhattan, New York, USA, throughout the study period were always $<2 \mathrm{~m}$ and usually $<1 \mathrm{~m}$; microscopic examination of the suspended particles indicated that turbidity was dominated by suspended detritus (including suspended clay and abiotic mineral particles) but also included phytoplankton.

To measure the rate and extent of radiotracer sorption to suspended particles in the Hudson, replicate 11 aliquots of water $(24 \%)$ in sterilized, acid-washed, screw-cap flasks each received $37 \mathrm{kBq}$ of ${ }^{110 \mathrm{~m}} \mathrm{Ag}$ (10 $\mathrm{nM} \mathrm{Ag}$ added) or $37 \mathrm{kBq}$ of ${ }^{210} \mathrm{~Pb}(62 \mathrm{fM} \mathrm{Pb}$ added), following the same protocol as with the Fabrea salina cultures. The flasks were swirled and periodically samples were taken to measure the size fractionation of the radiotracers in suspension. Samples were filtered in parallel through $10 \mu \mathrm{m}(20 \mathrm{ml}$ filtered), $3 \mu \mathrm{m}(20 \mathrm{ml})$, $1 \mu \mathrm{m}(20 \mathrm{ml})$, or $0.2 \mu \mathrm{m}(250 \mathrm{ml})$ Nuclepore polycarbonate membranes and the filters were washed with two $5 \mathrm{ml}$ rinses of filtered non-radioactive Hudson water. The dry weight of suspended particles in this water was $8.0 \mathrm{mg} \mathrm{l}^{-1}>1 \mu \mathrm{m}$, and $9.3 \mathrm{mg} \mathrm{l}^{-1}>0.2 \mu \mathrm{m}$.

In addition, the filtrate from the $0.2 \mu \mathrm{m}$ filters was immediately ultrafiltered in parallel, using an Amicon 8400 stirred cell under positive pressure of $\mathrm{N}_{2}$, to determine the extent to which the metals associated with colloidal-sized particles in the water. Ultrafiltration cut-offs were $300 \mathrm{kDa}$ (Amicon XM 300 acrylic polymer) and $50 \mathrm{kDa}$ (XM 50 acrylic polymer). Preliminary experiments indicated that adsorption of these isotopes (dissolved in ultrafiltered water) to these ultrafilters was $<2 \%$. Radioactivity in $2 \mathrm{ml}$ aliquots of filtrate from each ultrafilter were measured (as above) and the fractionation of each radioisotope determined by difference.

The radioactivity of the filters and of unfiltered aliquots of water were determined using a PharmaciaWallac Compugamma equipped with a $\mathrm{NaI}(\mathrm{Tl})$ crystal and Ultroterm software. The $\gamma$-emissions of ${ }^{110 \mathrm{~m}} \mathrm{Ag}$ were detected at $658 \mathrm{keV}$ and of ${ }^{210} \mathrm{~Pb}$ at $46 \mathrm{keV}$. The counting times were adjusted to yield propagated counting errors $<5 \%$.

To measure the fractionation of stable metals on particles, suspended particulate matter was digested using a $\mathrm{HNO}_{3}-\mathrm{HClO}_{4}-\mathrm{HF}$ acid digestion technique (Trefry \& Trocine 1991). Metal analyses of the digest solutions were performed using a Perkin-Elmer Zeeman 5000 atomic absorption spectrophotometer (AAS) equipped with an HGA-500 graphite atomizer and an AS-40 autosampler. Fe and Mn analyses were performed using an air-acetylene flame, $\mathrm{Al}$ using a $\mathrm{N}_{2} \mathrm{O}$ acetylene flame, and $\mathrm{Pb}$ and $\mathrm{Ag}$ using flameless AAS. Magnesium nitrate and ammonium phosphate matrix modifiers were used in the flameless analyses of $\mathrm{Ag}$ and $\mathrm{Pb}$, respectively.

National Research Council Canada MESS-1 reference marine sediment for trace elements was digested 
and analyzed with the Hudson samples to determine the accuracy of the digest-AAS method. Comparison of the measured and expected mean values of MESS-1 marine sediment yielded recoveries of $109 \%$ for $\mathrm{Al}$, $100 \%$ for $\mathrm{Fe}, 87 \%$ for $\mathrm{Mn}$, and $100 \%$ for $\mathrm{Pb}$. $\mathrm{A}$ MESS-1 certified value for Ag has not been established. Acid and filter blanks were $<5 \%$ of the total sample signal for all digest elemental analyses.

\section{RESULTS}

\section{Accumulation of $\mathrm{Ag}$ and $\mathrm{Pb}$ by ciliates}

Fabrea salina cells accumulated Ag from both dissolved and particulate sources (Fig. 2). Concentration factors on a volume/volume basis (VCFs) were determined by dividing the radioactivity per $\mu^{3}$ of cell by radioactivity per $\mu^{3}$ of water (in the dissolved phase). There was no appreciable change in the VCFs for Ag accumulated from the dissolved phase after the first sample at $4 \mathrm{~h}$, suggesting that uptake was complete by $4 \mathrm{~h}$. In contrast, VCF values for ingested Ag increased steadily between 4 and $25 \mathrm{~h}$ (Fig. 2). In the experimental results shown in Fig. 2, the Ag VCFs at $25 \mathrm{~h}$ were about $7 \times 10^{3}$ from both dissolved and ingested sources and the $\mathrm{Pb}$ VCF was $2 \times 10^{2}$. In a separate experiment with a different batch of ciliates and different experimental water (although prepared identically), mean Ag VCFs were calculated at $24 \mathrm{~h}$ to be $3.6 \pm 1.1 \times 10^{4}$ from the dissolved phase and $4.1 \pm 1.2 \times$ $10^{4}$ from ingested food. Thus, there is some variation in VCFs, yielding a mean VCF from the 2 sets of experiments of approximately $2 \times 10^{4}$ for Ag.

Clearance of food vacuoles in Fabrea salina for $1 \mathrm{~h}$ had a small effect on Ag accumulation in the ciliate from ingested food (Fig. 3), suggesting that measure-

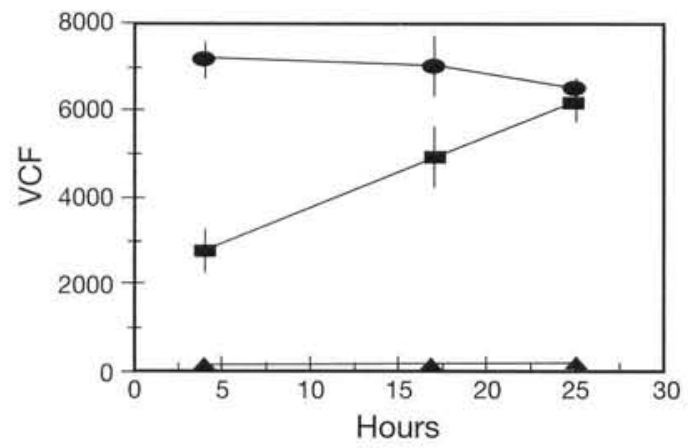

Fig. 2. Fabrea salina. Accumulation of $\mathrm{Ag}$ and $\mathrm{Pb}$ over time. Values presented are calculated volume/volume concentration factors (VCF) for Ag from the dissolved phase only (•) or from algal food (a) and for $\mathrm{Pb}$ from the dissolved phase only (4). Data points are means of 2 replicates and are shown with 1 SD error bars. Propagated counting errors were $<5 \%$

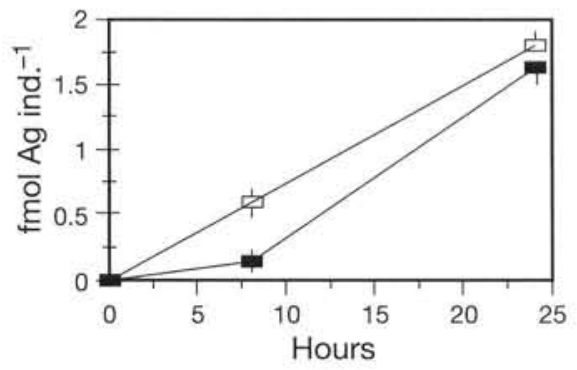

Fig. 3. Fabrea salina. Ag content per ciliate over time, before (ㅁ) and after (घ) gut evacuation. Ag content of each individual was determined by converting the radioactivity ind ${ }^{-1}$ to total $\mathrm{Ag}$ ind $\mathrm{d}^{-1}$ using the specific activity of the radiotracer. Data points are means of 2 replicates and are shown with 1 SD error bars. Propagated counting errors were $<5 \%$

ments of ${ }^{110 \mathrm{~m}} \mathrm{Ag}$ in these organisms reflected levels of assimilated Ag, since boluses of unassimilated food containing ${ }^{110 \mathrm{~m}} \mathrm{Ag}$ would have been excreted following vacuole evacuation. Some of the Ag accumulated by F. salina from feeding suspensions may have come from the dissolved phase, since Ag rapidly desorbed from the radiolabeled Isochrysis galbana cells (Fig. 4). However, the different kinetics of Ag uptake displayed by the ciliates from dissolved and particulate sources (Fig. 2) suggest that ingested food was a significant source of $\mathrm{Ag}$. The ${ }^{210} \mathrm{~Pb}$ content in $F$. salina obtained by feeding on radiolabeled $I$. galbana was below detection, suggesting that there was little or no assimilation of this isotope in the ciliates from the radiolabeled food.

\section{Fractionation of $\mathrm{Ag}$ and $\mathrm{Pb}$ added to Hudson River water}

The size fractionation of ${ }^{110 \mathrm{~m}} \mathrm{Ag}$ and ${ }^{210} \mathrm{~Pb}$ added to the Hudson water containing the natural particle assemblages is presented in Fig. 5. Fifteen minutes after adding the radioisotopes, $84 \%$ of the ${ }^{110 \mathrm{~m}} \mathrm{Ag}$ was

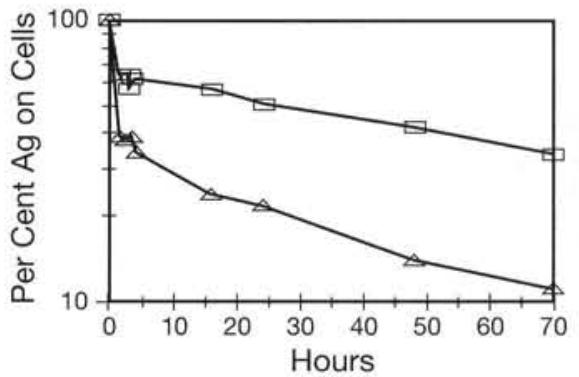

Fig. 4. Isochrysis galbana. Loss of ${ }^{110 \mathrm{~m}} \mathrm{Ag}$ from radiolabeled cells resuspended into unlabeled seawater. Two cell densities, $5.6 \times 10^{4}$ cells ml ${ }^{-1}(\Delta)$ and $4.5 \times 10^{5}$ cells ml ${ }^{-1}(\square)$, were compared. Propagated counting errors were $<5 \%$ 

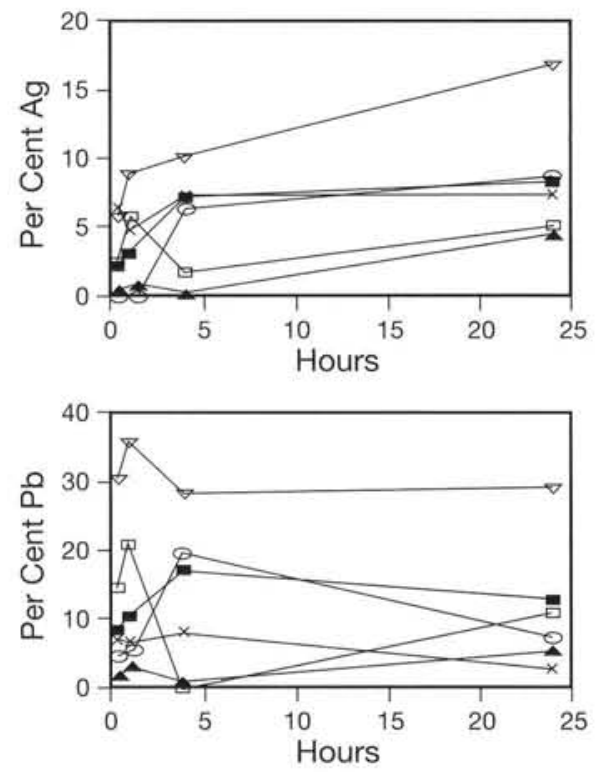

Fig. 5. Size fractionation of ${ }^{110 \mathrm{~m}} \mathrm{Ag}$ and ${ }^{210} \mathrm{~Pb}$ added to Hudson River water over time. Values plotted are percentages of total radioactivity in each fraction. $(\mathbf{m})>10 \mu \mathrm{m}$ fraction; $(\nabla) 3$ to $10 \mu \mathrm{m}$ fraction; (ㅇ) 1 to $3 \mu \mathrm{m}$ fraction; (ㅁ) 0.2 to $1 \mu \mathrm{m}$ fraction; ( $\times$ ) $300 \mathrm{kDa}$ to $0.2 \mu \mathrm{m}$ fraction; ( $\mathbf{\Delta}$ ) denotes 50 to $300 \mathrm{kDa}$ fraction. Propagated counting errors were $<5 \%$

in the dissolved phase (i.e. $<50 \mathrm{kDa}$ ), the remainder being bound principally to particles in the 3 to $10 \mu \mathrm{m}$ range $(5.7 \%)$ and to colloidal matter larger than $300 \mathrm{kDa}(6.3 \%)$. Over the ensuing $24 \mathrm{~h}$, the dissolved ${ }^{110 \mathrm{~m}} \mathrm{Ag}$ decreased to $50 \%$ of the total, with the largest fraction being bound to particles in the 3 to $10 \mu \mathrm{m}$ range $(16.7 \%)$; approximately equal amounts were bound to particles in the 1 to $3 \mu \mathrm{m}(8.3 \%)$ and the $>10 \mu \mathrm{m}$ ranges $(8.5 \%)$. The fraction of the total ${ }^{110 \mathrm{~m}} \mathrm{Ag}$ bound to the large colloidal matter ( $>300 \mathrm{kDa}$ ) stayed constant over time, while that in the smaller colloidal pool ( 50 to $300 \mathrm{kDa}$ ) increased to $4.3 \%$ at $24 \mathrm{~h}$. The largest changes after $4 \mathrm{~h}$ were in the 3 to $10 \mu \mathrm{m}$ fraction and the smaller colloidal pool (Fig. 5). The dissolved ${ }^{210} \mathrm{~Pb}$ stayed fairly constant over time at $<36 \%$ of the total, whereas the fraction of ${ }^{210} \mathrm{~Pb}$ bound to $>10 \mu \mathrm{m}$ particles increased from $7.8 \%$ at $15 \mathrm{~min}$ to $17 \%$ at $4 \mathrm{~h}$, then declined to $12.7 \%$ at $24 \mathrm{~h}$ (Fig. 5). This increase in the largest fraction was accompanied by a decrease in the 0.2 to $1 \mu \mathrm{m}$ particles (from $14.1 \%$ at $15 \mathrm{~min}$ to $0 \%$ at $4 \mathrm{~h}$, followed by an increase to $10.8 \%$ at $24 \mathrm{~h}$ ); the other size fractions for ${ }^{210} \mathrm{~Pb}$ remained fairly constant over time (Fig. 5). The dry weight concentration factors of ${ }^{110 \mathrm{~m}} \mathrm{Ag}$ and ${ }^{210} \mathrm{~Pb}$ for particles $(>0.2 \mu \mathrm{m})$ in this water were $6.67 \times 10^{4}$ and $1.52 \times 10^{5}$, respectively.

\section{Metals in suspended particulate matter}

Suspended particulate matter (SPM) concentrations in the Hudson River ranged from 8.0 to $30 \mathrm{mg} \mathrm{l}^{-1}$ for the samples collected during 1990 and 1991 (Table 1). Little difference was observed in the mass of particulates collected on different pore size filters during each sampling event. However, the mass of particles collected in March 1991 was less than those of the other samplings.

$\mathrm{Pb}$ contents of the Hudson River SPM ranged from 168 to $328 \mu^{-1} \mathrm{~g} \mathrm{~g}^{-1}$ while $\mathrm{Ag}$ contents of the Hudson River SPM ranged from 5.02 to $10.50 \mathrm{\mu g} \mathrm{g}^{-1}$ (Table 1). In general, metal concentrations of the SPM increased inversely with the size of the particles. Aluminum was used as a granulometric normalizer to account for the differences in the metal content of particles due to increased surface area of the smaller particles. The

Table 1. Metal content $\left(\mathrm{\mu g} \mathrm{g}^{-1}\right)$ of digested Hudson River suspended particulate matter (SPM) fractions collected at Pier 26, Lower Manhattan, New York. EF: enrichment factor, the observed metal/aluminium ratio divided by the metal/aluminium ratio reported for average crustal material (see Table 2); BDL: below detection limit for $\mathrm{Pb}$ of $150 \mu \mathrm{g} \mathrm{g}^{-1}$; $\mathrm{NC}$ : not calculated

\begin{tabular}{|c|c|c|c|c|c|c|c|c|c|c|c|c|c|c|c|}
\hline $\begin{array}{c}\text { Pore size } \\
(\mu \mathrm{m})\end{array}$ & $\begin{array}{c}\mathrm{SPM}^{\mathrm{a}} \\
\left(\mathrm{mg} \mathrm{1}^{-1}\right)\end{array}$ & $\begin{array}{l}\text { Digested } \\
\text { mass (mg }\end{array}$ & $\begin{array}{ll}\text { d } & \text { Al } \\
\text { g) } & \end{array}$ & $\mathrm{Fe}$ & $\begin{array}{l}\mathrm{Fe} / \mathrm{Al} \\
\left(\times 10^{3}\right)\end{array}$ & $\begin{array}{l}\mathrm{Fe} \\
\mathrm{EF}\end{array}$ & Mn & $\begin{array}{l}\mathrm{Mn} / \mathrm{Al} \\
\left(\times 10^{3}\right)\end{array}$ & $\begin{array}{l}\mathrm{Mn} \\
\mathrm{EF}\end{array}$ & $\mathrm{Pb}$ & $\begin{array}{l}\mathrm{Pb} / \mathrm{Al} \\
\left(\times 10^{3}\right)\end{array}$ & $\begin{array}{l}\mathrm{Pb} \\
\mathrm{EF}\end{array}$ & $\mathrm{Ag}$ & $\begin{array}{l}\mathrm{Ag} / \mathrm{Al} \\
\left(\times 10^{3}\right)\end{array}$ & $\begin{array}{l}\mathrm{Ag} \\
\mathrm{EF}\end{array}$ \\
\hline \multicolumn{16}{|c|}{ February 1990} \\
\hline 0.2 & 16.4 & 16.4 & 82200 & 51600 & 628 & 0.918 & 1080 & 13.1 & 1.14 & 218 & 2.65 & 17.6 & 10.50 & 0.13 & 144 \\
\hline 1.0 & 22.2 & 11.1 & 63000 & 41100 & 652 & 0.953 & 810 & 12.9 & 1.15 & 175 & 2.78 & 18.5 & 9.37 & 0.15 & 167 \\
\hline 3.0 & 19.4 & 9.7 & 60100 & 39000 & 649 & 0.949 & 719 & 12.0 & 1.07 & 168 & 2.79 & 18.6 & 7.56 & 0.13 & 144 \\
\hline \multicolumn{16}{|l|}{ July 1990} \\
\hline 0.2 & 22.0 & 5.5 & 59600 & 41300 & 693 & 1.01 & 930 & 15.6 & 1.39 & BDL & $\mathrm{NC}$ & $\mathrm{NC}$ & 9.68 & 0.16 & 178 \\
\hline 3.0 & 30.0 & 7.5 & 40500 & 23800 & 588 & 0.913 & 1320 & 32.6 & 2.91 & BDL & $\mathrm{NC}$ & $\mathrm{NC}$ & 7.17 & 0.18 & 200 \\
\hline 8.0 & 24.4 & 6.1 & 52400 & 17300 & 330 & 0.482 & 1240 & 23.7 & 2.12 & BDL & NC & NC & 5.02 & 0.10 & 111 \\
\hline \multicolumn{16}{|c|}{ March 1991} \\
\hline 0.2 & 9.3 & $9.3 \quad 1$ & 104500 & 36400 & 348 & 0.509 & 1250 & 11.9 & 1.06 & 328 & 3.14 & 20.9 & 8.62 & 0.08 & 89 \\
\hline 1.0 & 8.0 & 8.0 & 94500 & 51100 & 541 & 0.791 & 1240 & 13.1 & 1.17 & 245 & 2.59 & 17.3 & 8.51 & 0.09 & 100 \\
\hline
\end{tabular}


$\mathrm{SPM} \mathrm{Pb} / \mathrm{Al}$ ratio remained similar for each pore size fraction during each sampling (Table 1). The $\mathrm{Pb} / \mathrm{Al}$ ratio of the $>0.2 \mu \mathrm{m}$ fraction of the SPM collected in March 1991 was significantly higher than the $\mathrm{Pb}: \mathrm{Al}$ ratios for other SPM samples collected during this study. The SPM Ag: Al ratio also remained similar for each particle size for all samples (Table 1). However, the Ag: Al ratio of SPM collected in March 1991 was lower in comparison to the $\mathrm{Ag}: \mathrm{Al}$ ratios for SPM collected during February and July 1990.

Enrichment factors (EFs) were calculated for each metal during each sampling period to account for the natural concentrations of trace metals in suspended matter. EFs were calculated by dividing the observed metal/aluminum ratio by the metal/aluminum ratio reported for average crustal material (Taylor 1964). Significant $\mathrm{Pb}$ and $\mathrm{Ag}$ enrichment was observed for Hudson River water SPM collected during the 3 sampling events. $\mathrm{Pb}$ enrichment was similar, ranging from 17.3 to 20.9 for SPM retained on the $1.0 \mu \mathrm{m}$ and $0.2 \mu \mathrm{m}$ filters, respectively, collected on July 30, 1990 (Table 1). Ag enrichment varied from 89 for SPM retained on the $0.2 \mu \mathrm{m}$ filter collected on March 27, 1991 to 200 for SPM collected on the $3.0 \mu \mathrm{m}$ filter collected on July 30 , 1990. $\mathrm{Pb}$ and $\mathrm{Ag}$ concentrations of lower Hudson River SPM are enriched in comparison to $\mathrm{Pb}$ and $\mathrm{Ag}$ EFs calculated for the Mississippi River, average world rivers, and upper Hudson River SPM (Table 2).

Table 3 presents a comparison of the fractionation of radiolabeled (from Fig. 5) and stable (computed from the data in Table 1, assuming a constant concentration factor for radiolabeled and stable metal) $\mathrm{Ag}$ and $\mathrm{Pb}$ among particulate and dissolved (i.e. $<0.2 \mu \mathrm{m}$ ) phases in the Hudson at 3 different sampling times. The fraction of total metal in particulate form increased with suspended particle load, which varied with sample time. The fractionation of radiolabeled and stable Ag and $\mathrm{Pb}$ were generally comparable with each other; e.g. the greatest fractions for each metal were the dissolved fraction and the largest particle size fraction $(>3 \mu \mathrm{m})$. Because the particle loads (and therefore the fraction of total metal on particles) differed at the different sample times, comparisons of metal fractionation on different particle sizes between samples is facilitated by comparing the percentage of total particulate metal in each size fraction for each sample. Of the total particulate $\mathrm{Ag}, 12.5 \%$ of the ${ }^{110 \mathrm{~m}} \mathrm{Ag}$ and $18.4 \%$ of the ${ }^{210} \mathrm{~Pb}$ were in the bacterial-sized fraction ( 0.2 to $1 \mu \mathrm{m}$ ), compared with $10.8 \%$ of stable $\mathrm{Ag}$ and $19.7 \%$ of stable $\mathrm{Pb}$ at the February sampling. $\mathrm{Ag}$ generally displayed a greater fractionation in the 1 to $3 \mu \mathrm{m}$ particles than did $\mathrm{Pb}$, which was more enriched in the smallest particles (Table 3). Although dissolved metal concentrations were not measured in the field samples, total (dissolved plus particulate) metal concentrations for each field sample were computed using the measured concentration factors for each radioisotope $\left({ }^{110 \mathrm{~m}} \mathrm{Ag}: 6.67 \times 10^{4} ;{ }^{210} \mathrm{~Pb}: 1.52 \times 10^{5}\right)$ and the particulate metal concentrations given in Table 1 ; total Ag concentrations were 1.9 to $3.1 \mathrm{nM}$, total $\mathrm{Pb} 23$ to $24 \mathrm{nM}$ (Table 3).

\section{DISCUSSION}

The results suggest that $\mathrm{Ag}$ is more likely than $\mathrm{Pb}$ to accumulate in estuarine protozoa because it binds more strongly to cell surfaces from the dissolved phase than does $\mathrm{Pb}$ and because $\mathrm{Ag}$ is assimilated to a much greater extent than $\mathrm{Pb}$ from ingested algal food. Since Ag is accumulated more than $\mathrm{Pb}$ in these cells, Ag (but not $\mathrm{Pb}$ ) should be transferred biologically within the microbial food web and could accumulate to levels which are toxic to some organisms; toxic responses (e.g. depression of growth rate or metabolic processes) of planktonic organisms are only to cellular metal burdens, not ambient metal (Davies 1978). The mean concentration factor for Ag in Fabrea salina $\left(2 \times 10^{4}\right)$ was near the mean VCF $\left(3 \times 10^{4}\right)$ for nanoplanktonsized algal cells (Fisher 1986), which have higher surface to volume ratios. Differences between Pb VCFs in F. salina $\left(2 \times 10^{2}\right)$ and nanoplankton $\left(5 \times 10^{4}\right.$; Fisher

Table 2. Total metal content ( $\mathrm{g} \mathrm{g} \mathrm{g}^{-1}$ ) in the Hudson River and Mississippi River suspended particulate matter (SPM), suspended particles from average world rivers and average continental crust. EF: enrichment factor; BDL: below detection limit for Ag of $0.4 \mu \mathrm{g} \mathrm{g}^{-1}$; NC: not calculated; ND: not determined

\begin{tabular}{|c|c|c|c|c|c|c|c|c|c|c|c|c|c|}
\hline & $\mathrm{Al}$ & $\mathrm{Fe}$ & $\begin{array}{l}\mathrm{Fe} / \mathrm{Al} \\
\left(\times 10^{3}\right)\end{array}$ & $\mathrm{Fe} E F$ & Mn & $\begin{array}{l}\mathrm{Mn} / \mathrm{Al} \\
\left(\times 10^{3}\right)\end{array}$ & Mn EF & $\mathrm{Pb}$ & $\begin{array}{l}\mathrm{Pb} / \mathrm{Al} \\
\left(\times 10^{3}\right)\end{array}$ & $\mathrm{Pb} \mathrm{EF}$ & $\mathrm{Ag}$ & $\begin{array}{l}\mathrm{Ag} / \mathrm{Al} \\
\left(\times 10^{3}\right)\end{array}$ & $\mathrm{Ag} \mathrm{EF}$ \\
\hline Hudson River $^{\mathrm{a}}$ & 55900 & 29200 & 522 & 0.763 & 3225 & 57.6 & 5.01 & 52 & 0.93 & 6.20 & BDL & $\mathrm{NC}$ & NC \\
\hline Mississippi River ${ }^{b}$ & 81300 & 41700 & 513 & 0.750 & 1220 & 15.0 & 1.304 & 33 & 0.41 & 2.73 & ND & $\mathrm{NC}$ & $\mathrm{NC}$ \\
\hline Average world rivers ${ }^{c}$ & 94000 & 48000 & 511 & 0.747 & 1050 & 11.2 & 0.974 & 100 & 1.06 & 7.07 & 0.07 & 0.0008 & 0.889 \\
\hline Continental crust $^{\mathrm{d}}$ & 82300 & 56300 & 684 & 1.000 & 950 & 11.5 & 1.000 & 12.5 & 0.15 & 1.00 & 0.07 & 0.0009 & 1.000 \\
\hline
\end{tabular}


Table 3. Fractionation (as \% of total) of radioactive and stable Ag and $\mathrm{Pb}$ in laboratory (radioactive metals) and field (stable metals) measurements. \% $\mathrm{P}$ : the fraction of total particulate metal in each particle size fraction. The calculated total $\mathrm{Ag}$ and $\mathrm{Pb}$ concentrations (dissolved plus particulate) in February were 2.9 and $23 \mathrm{nM}$, in July $3.1 \mathrm{nM}$ and below detection (BDL), and in March 1.9 and $24 \mathrm{nM}$, respectively

\begin{tabular}{|c|c|c|c|c|c|}
\hline $\begin{array}{l}\text { Particle size } \\
\text { fraction }\end{array}$ & $\begin{array}{l}\text { Sample: } \\
\text { Particle load: }\end{array}$ & $\begin{array}{l}\text { Laboratory } \\
9.3{\mathrm{mg} 1^{-1}}^{-1}\end{array}$ & $\begin{array}{l}\text { Field (Feb) } \\
19.3{\mathrm{mg} 1^{-1}}^{-1}\end{array}$ & $\begin{array}{l}\text { Field (Jul) } \\
25.5 \mathrm{mg} \mathrm{I}^{-1}\end{array}$ & $\begin{array}{l}\text { Field (Mar) } \\
8.7 \mathrm{mg} \mathrm{l}^{-1}\end{array}$ \\
\hline \multicolumn{6}{|l|}{$\mathrm{Ag}$} \\
\hline$<0.2 \mu \mathrm{m}$ & & 61.7 & 43.7 & 37 & 63.4 \\
\hline $0.2-1 \mu \mathrm{m}$ & & $4.8(12.5 \% \mathrm{P})$ & $6.1(10.8 \% \mathrm{P})$ & $16.4(26 \% \mathrm{P})^{\mathrm{a}}$ & $0.5(1.4 \% \mathrm{P})$ \\
\hline $1-3 \mu \mathrm{m}$ & & $8.3(21.7 \% \mathrm{P})$ & $9.7(17.2 \% \mathrm{P})$ & - & $36.1(98.6 \% \mathrm{P})^{\mathrm{b}}$ \\
\hline$>3 \mu \mathrm{m}$ & & $25.2(65.8 \% \mathrm{P})$ & $40.5(71.9 \% \mathrm{P})$ & $46.6(74 \% \mathrm{P})$ & - \\
\hline \multicolumn{6}{|l|}{$\mathrm{Pb}$} \\
\hline$<0.2 \mu \mathrm{m}$ & & 41.4 & 25.4 & $\mathrm{BDL}$ & 43.2 \\
\hline $0.2-1 \mu \mathrm{m}$ & & $10.8(18.4 \% \mathrm{P})$ & $14.7(19.7 \% \mathrm{P})$ & $\mathrm{BDL}$ & $14.4(25.4 \% \mathrm{P})$ \\
\hline $1-3 \mu \mathrm{m}$ & & $6.6(11.3 \% \mathrm{P})$ & $2.4(3.2 \% \mathrm{P})$ & BDL & $42.4(74.6 \% \mathrm{P})^{\mathrm{b}}$ \\
\hline$>3 \mu \mathrm{m}$ & & $41.2(70.3 \% \mathrm{P})$ & $57.5(77.1 \% \mathrm{P})$ & $\mathrm{BDL}$ & - \\
\hline
\end{tabular}

1986) were far more pronounced; unlike $\mathrm{Ag}, \mathrm{Pb}$ remains almost entirely on plankton surfaces without penetrating into cytoplasm (Schultz-Baldes \& Lewin 1976, Fisher et al. 1983b, Reinfelder \& Fisher 1991).

The speciation of these metals can, of course, significantly influence their bioavailability to estuarine organisms. These metals may enter the lower Hudson via discharges from municipal and industrial wastewater treatment plants, urban runoff, and atmospheric fallout. If Ag, which can enter the Hudson estuary through municipal wastewater discharge (Lytle 1984), speciates as thiosulfate (e.g. from photoprocessing procedures, for example), it may be orders of magnitude less available and less toxic to resident organisms than free Ag ion (LeBlanc et al. 1984). In oxygenated saline waters, $\mathrm{AgCl}^{0}, \mathrm{AgCl}_{2}^{-}$, and $\mathrm{AgCl}_{3}{ }^{2-}$ would be expected to be the dominant forms, although any sulfide present could precipitate Ag or perhaps result in the production of $\mathrm{Ag}_{2} \mathrm{~S}$ colloidal particles (which may have accounted for the small amount of colloidal Ag detected in the fractionation experiment). The bioavailability of chloro-complexes of Ag still requires further study, but there is some evidence that zerocharge chloro-complexes, which are non-polar, may be particularly reactive for estuarine organisms (Engel et al. 1981). $\mathrm{Pb}$ would be expected to form chloro- and especially carbonate-complexes (Florence \& Batley 1980). In addition, both $\mathrm{Ag}$ and $\mathrm{Pb}$ may be appreciably complexed by dissolved organic matter in natural waters (Florence \& Batley 1980, Whitlow \& Rice 1985) which could also influence their bioavailability. We did not directly determine the speciation of the metals after they were added (in ionic form) to the experimental water, but the speciation was such that concentration factors in the particles, living and abiotic, were comparable to what can be determined by analyzing natural particle assemblages in these same waters for stable $\mathrm{Ag}$ and $\mathrm{Pb}$.

At the same site in the Hudson, $\mathrm{Ag}$ and $\mathrm{Pb}$ were shown to fractionate between dissolved and particulate phases (Brosnan \& O'Shea 1993) to yield calculated partition coefficients (on dry weight bases) for suspended particulate matter of $1.5 \times 10^{5}$ and $4.8 \times 10^{5}$, respectively, comparable to concentration factors reported for diverse phytoplankton species (Fisher 1986); these values are somewhat greater (by 2 to $3 \times$ ) than the concentration factors for total suspended particles in our samples. The suspended particles in the lower Hudson, enriched with Ag, would also serve as an enriched source of this metal for organisms which ingest these particles, including protozoa. The results of the present study suggest that ingested $\mathrm{Pb}$ would not be assimilated in protozoa. The dry weight concentration factors estimated for Ag in Fabrea salina in different experiments, 0.5 to $3.0 \times 10^{5}$, were comparable to the concentration factor for this metal estimated from Brosnan \& O'Shea's data; the dry weight concentration factor for $\mathrm{Pb}$ in $F$. salina, $1.5 \times 10^{3}$, was significantly lower.

As noted above, the fractionation of the radiolabeled $\mathrm{Ag}$ and $\mathrm{Pb}$ in the Hudson River water with its natural assemblage of particles after $24 \mathrm{~h}$ was similar to the distribution of the stable forms of these metals measured in Hudson River particulate matter. This suggests that the radiotracer metal additions to the water speciated comparably with the naturally occurring metal in the same sample of Hudson water, further indicating that the results obtained from radiotracer partitioning among the particles was applicable to understanding the behavior of these metals under in situ conditions. $\mathrm{Pb}$, which is more particlereactive than $\mathrm{Ag}$ and penetrates less into cells, was 
relatively more enriched than $\mathrm{Ag}$ in the smallest particles which have the highest surface-to-volume ratios (Table 3 ). Both metals were appreciably associated (approximately $70 \%$ ) with the $>3 \mu \mathrm{m}$ fraction, which would contain the microzooplankton. The fractionation of the radioisotopes further suggests that colloidally associated metal may be a significant fraction of the metal in natural waters, particularly for $\mathrm{Pb}$. Recent studies have demonstrated that some metals can significantly associate with marine colloidal particles in the low nm size range (Whitehouse et al. 1990, Wells \& Goldberg 1991), and these colloidally bound metals may bind to larger particles (microorganisms included) by the association of the colloids with the larger particles, i.e. by particle-particle interactions (Honeyman \& Santschi 1991). There are few published studies quantifying the colloidal association of $\mathrm{Ag}$ and $\mathrm{Pb}$ in estuarine waters, although recent data indicate that colloids in estuarine waters can be enriched in these and other metals (Benoit et al. 1994), consistent with our findings.

The $\mathrm{Ag}$ and $\mathrm{Pb}$ concentrations in suspended particulate matter from the lower Hudson River were higher than those in samples taken near Annandale, New York, $160 \mathrm{~km}$ to the north. The $\mathrm{Pb}$ and Ag contents of the lower Hudson river SPM are similar to their concentrations reported for fine grain sediments $(<63 \mu \mathrm{m})$ in the Hudson Raritan Estuary. Pb contents of the fine grain sediments of the estuary range from $210 \mathrm{\mu g} \mathrm{g}^{-1}$ in Jamaica Bay, New York to $280 \mu \mathrm{g} \mathrm{g}^{-1}$ in Raritan Bay, New Jersey; Ag contents of the fine grain sediments within the estuary range from $5.0 \mathrm{\mu g} \mathrm{g}^{-1}$ in the upper Hudson Bay, New York to $7.2 \mu \mathrm{g} \mathrm{g}^{-1}$ in Raritan Bay (NOAA 1991). Brosnan \& O'Shea (1993) report Ag and $\mathrm{Pb}$ concentrations in bulk sediments of the lower Hudson of $20 \mu^{-1} \mathrm{~g} \mathrm{~g}^{-1}$ and $176 \mu \mathrm{g} \mathrm{g}^{-1}$, respectively. Given the similarity of the metal concentrations, it may be that a substantial fraction of the SPM analyzed in our study was resuspended fine grain sediments. The $\mathrm{Ag}$ and $\mathrm{Pb}$ values reported here were substantially greater than values reported for the Mississippi (Metz 1986) and for global river averages (Martin \& Whitfield 1983) and average crustal material (Taylor 1964). The results suggest that these metals have primarily an anthropogenic origin in the Hudson, consistent with findings in the Southern California Bight (SanudoWilhelmy \& Flegal 1992).

Windom et al. (1991) argue that the best approximation of the natural composition of suspended sediment of a river on the east coast of the United States is the average metal/aluminum ratio in samples having a total suspended solids load $>15 \mathrm{mg} \mathrm{l}^{-1}$. The metal/aluminum ratio at high suspended loads allows for an estimation of the anthropogenic compo- nent of the metal of interest. Although 2 of the 3 samples collected during this study have SPM loads $>15 \mathrm{mg} \mathrm{l}^{-1}$, the high enrichment factors observed for $\mathrm{Pb}$ and $\mathrm{Ag}$ indicate that these samples may not be representative of the natural composition of Hudson River SPM (Table 1). Because $\mathrm{Ag} / \mathrm{Al}$ and $\mathrm{Pb} / \mathrm{Al}$ values for East Coast rivers with total SPM loads $>15 \mathrm{mg}^{-1}$ have not been reported, the average world river values of $0.8 \times 10^{-6}$ for $\mathrm{Ag}$ and $1.06 \times$ $10^{-7}$ for $\mathrm{Pb}$ were selected. Using these ratios, $>86 \%$ of the $\mathrm{Pb}$ and $>99 \%$ of the $\mathrm{Ag}$ associated with the SPM collected in this study in the lower Hudson could be considered to be anthropogenic.

The role of the microzooplankton in influencing energy flow and the biogeochemical cycles of $\mathrm{C}, \mathrm{N}$ and $\mathrm{P}$ has been shown to be significant in a variety of aquatic habitats. Relatively little is known, however, of the role of this group in the biogeochemistry of trace metals. From the results of this study, it appears that planktonic ciliates could be significant in concentrating both $\mathrm{Ag}$ and $\mathrm{Pb}$ out of ambient water and, in the case of Ag at least, passage into the food web. The ultimate biogeochemical and toxicological significance of these processes remains to be determined.

Acknowledgements. We thank S. Dunham and M. Wente for technical assistance, C. Drew, C. Nieder, and G. Benoit for useful discussions, and 3 anonymous reviewers for helpful comments. We appreciate access to the facilities of The River Project in Manhattan and the National Estuarine Research Reserve field station in Annandale, New York. This is MSRC Contribution No. 956. This work was supported by grants from the Hudson River Foundation and NOAA Award No. R/CTP-10. The U.S. Government is authorized to produce and distribute reprints for governmental purposes notwithstanding any copyright notation that may appear hereon. The views expressed herein are those of the authors and do not necessarily reflect the views of NOAA or any of its subagencies.

\section{LITERATURE CITED}

Benoit, G., Oktay-Marshall, S. D., Cantu, A., Hood, E. M. Coleman, C. H., Corapcioglu, M. O., Santschi, P. H. (1994). Partitioning of $\mathrm{Cu}, \mathrm{Pb}, \mathrm{Ag}, \mathrm{Zn}, \mathrm{Fe}, \mathrm{Al}$, and $\mathrm{Mn}$ between filter-retained particles, colloids, and solution in six Texas estuaries. Mar. Chem. 45: 307-336

Berk, S. G., Brownlee, D. C., Heinle, D. R., Kling, H. J., Colwell, R. R. (1977). Ciliates as a food source for marine planktonic copepods. Microb. Ecol. 4: 27-40

Berk, S. G., Gunderson, J. H., Berk, L. A. (1986). Effects of cadmium and copper on chemotaxis of marine and freshwater ciliates. Bull. Environ. Contam. Toxicol. 34: 897-903

Brosnan, T. M., O'Shea, M. L. (1993). New York Harbor water quality survey: 1991-1992. Final report. City of New York, Department of Environmental Protection

Capriulo, G. M., Carpenter, E. J. (1983). Abundance, species composition and impact of tintinnid microzooplankton in central Long Island Sound. Mar. Ecol. Prog. Ser. 10: $277-288$ 
Caron, D. A., Goldman, J. C. (1990). Protozoan nutrient regeneration. In: Capriulo, G. M. (ed.) Ecology of marine protozoa. Oxford University Press, New York, p. 283-306

Davies, A. G. (1978). Pollution studies with marine plankton. Part II. Heavy metals. Adv. mar. Biol. 15: 381-508

Engel, D. W., Sunda, W. G., Fowler, B. A. (1981). Factors affecting trace metal uptake and toxicity to estuarine organisms. I. Environmental parameters. In: Vernberg, F. J., Calabrese, A., Thurberg, F. T., Vernberg, W. B. (eds.) Biological monitoring of marine pollutants. Academic Press, New York, p. 127-142

Fisher, N. S. (1985). Accumulation of metals by marine picoplankton. Mar. Biol. 87: 137-142

Fisher, N. S. (1986). On the reactivity of metals for marine phytoplankton. Limnol. Oceanogr. 31: 443-449

Fisher, N. S., Bjerregaard, P., Fowler, S. W. (1983a). Interactions of marine plankton with transuranic elements. 1. Biokinetics of neptunium, plutonium, americium, and californium in phytoplankton. Limnol. Oceanogr. 28: 432-447

Fisher, N. S., Bohé, M., Teyssié, J.-L. (1984). Accumulation and toxicity of $\mathrm{Cd}, \mathrm{Zn}, \mathrm{Ag}$ and $\mathrm{Hg}$ in four marine phytoplankters. Mar. Ecol. Prog. Ser. 18: 201-213

Fisher, N. S., Burns, K. A., Cherry, R. D., Heyraud, M. (1983b). Accumulation and cellular distribution of ${ }^{241} \mathrm{Am},{ }^{210} \mathrm{Po}$, and ${ }^{210} \mathrm{~Pb}$ in two marine algae. Mar. Ecol. Prog. Ser. 11: 233-237

Fisher, N. S., Wente, M. (1993). The release of trace elements by dying marine phytoplankton. Deep Sea Res. 40: 671-694

Florence, T. M., Batley, G. E. (1980). Chemical speciation in natural waters. CRC Crit. Rev. analyt. Chem. 9: 219-296

Gold, K., Morales, E. A. (1975). Seasonal changes in lorica sizes and the species of Tintinnida in the New York Bight. J. Protozool. 22: 520-528

Heinbokel, J. F., Beers, J. R. (1979). Studies on the functional role of tintinnids in the Southern California Bight. III. Grazing impact of natural assemblages. Mar. Biol. 52: $23-32$

Honeyman, B. D., Santschi, P. H. (1991). Coupling adsorption and particle aggregation: laboratory studies of 'colloidal pumping' using ${ }^{59} \mathrm{Fe}$-labeled hematite. Environ. Sci. Technol. 25: 1739-1747

Hutchins, D. A., Bruland, K. W. (1994). Grazer-mediated regeneration and assimilation of $\mathrm{Fe}, \mathrm{Zn}$ and $\mathrm{Mn}$ from planktonic prey. Mar. Ecol. Prog. Ser. 110: 259-269

Kentouri, M., Divanach, P. (1986). Sur l'importance des cilies pelagiques dans l'alimentation des stades larvaires de poissons. Ann. Biol. 25: 307-318

LeBlanc, G. A., Mastone, J. D., Paradice, A. P., Wilson, B. F., Lockhart, H. B., Robillard, K. A. (1984). The influence of speciation on the toxicity of silver to fathead minnow (Pimephales promelas). Environ. Toxicol. Chem. 3: 37-46

Lonsdale, D. J., Cosper, E. M. (1994). Phytoplankton productivity and zooplankton feeding and productivity in the lower Hudson River estuary. Final Rep. to Hudson River Fndn

Lytle, P. E. (1984). Fate and speciation of silver in publicly owned treatment works. Environ. Toxicol. Chem. 3: 24-30

Martin, J. M., Whitfield, M. (1983). The significance of the river input of chemical elements to the ocean. In: Wong, C. S., Boyle, E., Bruland, K. W., Goldberg, E. D. (eds.) Trace metals in sea water. Plenum Press, New York, p. 265-296

Metz, S. (1986). Metal enrichment processes in the marine environment. Ph.D. dissertation, Florida Institute of Technology

NOAA (1989). A summary of data on tissue contamination from the first three years (1986-1988) of the Mussel Watch project. NOAA Tech. Mem. NOS OMA 49, Rockville, MD

NOAA (1991). Secondary summary of data on chemical contaminants in sediments from the National Status and Trends Program. NOAA Tech. Mem. NOS OMA 59, Rockville, MD

Reinfelder, J. R., Fisher, N. S. (1991). The assimilation of elements ingested by marine copepods. Science 251: 794-796

Repak, A. J. (1983). Suitability of selected marine algae for growing the marine heterotrich ciliate Fabrea salina. J. Protozool. 30: 52-54

Rivkin, R. (1979). Effects of lead on growth of the marine diatom, Skeletonema costatum. Mar. Biol. 50: 239-247

Robertson, J. R. (1983). Predation by estuarine zooplankton on tintinnid ciliates. Estuar. coast. Shelf Sci. 16: 27-36

Sanudo-Wilhelmy, S. A., Flegal, A. R. (1992). Anthropogenic silver in the Southern California Bight: a new tracer of sewage in coastal waters. Environ. Sci. Technol. 26: $2147-2151$

Schultz-Baldes, M., Lewin, R. A. (1976), Lead uptake in two marine phytoplankton organisms. Biol. Bull. 150: 118-127

Sherr, E. B., Sherr, B. F. (1987). High rates of consumption of bacteria by pelagic ciliates. Nature 325: 710-711

Small, L. F., Ellis, S. G. (1992). Fecal carbon production by zooplankton in Santa Monica Basin: the effects of body size and carnivory. Prog. Oceanogr. 30: 197-221

Stoecker, D. K., Capuzzo, J. M. (1990). Predation on protozoa: its importance to zooplankton. J. Plankton Res. 12: 891-908

Stoecker, D. K., Verity, P., Michaels, A., Davis, L. (1987). Feeding by larval and postlarval ctenophores on microzooplankton. J. Plankton Res. 9: 667-683

Taylor, S. R. (1964). Abundance of chemical elements in the continental crust: a new table. Geochim. Cosmochim. Acta 28: $1273-1285$

Trefry, J. H., Trocine, R. P. (1991). Collection and analysis of marine particles for trace elements. In: Marine particles: analysis and characterization. Geophys. Monogr. 63. American Geophysical Union, Washington, DC, p. $311-315$

Turner, J. T., Anderson, D. M. (1983). Zooplankton grazing during dinoflagellate blooms in a Cape Cod embayment, with observations of predation upon tintinnids by copepods. P.S.Z.N. I: Mar. Ecol. 4: 359-374

Wells, M. L., Goldberg, E. D. (1991). Occurrence of small colloids in sea water. Nature 353: 342-344

Whitehouse, B. G., Yeats, P. A., Strain, P. M. (1990). Crossflow filtration of colloids from aquatic environments. Limnol. Oceanogr. 35: 1368-1375

Whitlow, S. I., Rice, D. L. (1985). Silver complexation in river waters of central New York. Water Res. 5: 619-626

Windom, H. L., Byrd, J. T., Smith, R. G., Huan, F. (1991). Inadequacy of NASQAN data for assessing metal trends in the nation's rivers. Environ. Sci. Technol. 25: 1137-1142

Manuscript first received: January 18, 1994 Revised version accepted: September 5, 1994 